$\checkmark$ Research Square
Preprints are preliminary reports that have not undergone peer review.

They should not be considered conclusive, used to inform clinical practice, or referenced by the media as validated information.

\title{
High frequency plant regeneration of Chrysopogon zizanioides via organogenesis and somatic embryogenesis-an underutilized pharmaceutically valuable biofuel plant
}

\section{Merlin Monisha}

Annamalai University Faculty of Agriculture

\section{Prakash}

Annamalai University Faculty of Agriculture

\section{K.R. Saravanan}

Annamalai University Faculty of Agriculture

Anandan R ( $\square$ bioanandan@gmail.com )

Annamalai University https://orcid.org/0000-0002-0037-9191

\section{Research Article}

Keywords: Vetiver, Callus, Node, Organogenesis, Somatic embryo

Posted Date: November 1st, 2021

DOI: https://doi.org/10.21203/rs.3.rs-934878/v1

License: @ (i) This work is licensed under a Creative Commons Attribution 4.0 International License. Read Full License 


\section{Abstract}

Vetiver (Chrysopogon zizanioides) is an essential oil-producing plant that has tremendous application in cosmetics, perfumery, and herbal medicine. Natural sterility and indiscriminate harvests lead to the risk of extinction of plant species in natural habitats. Therefore, a protocol for regeneration systems via organogenesis and somatic embryogenesis using node, leaf, and root explants has been standardized. The highest shoot regeneration frequency $(72.2 \%)$ through organogenesis was attained from node explants on MS (Murashige \& Skoog) medium comprising $2.0 \mathrm{mg} \mathrm{L}^{-1}$ BAP ("6-benzylaminopurine"). Concurrently, leaf explants cultivated on MS medium augmented by $1.0 \mathrm{mg} \mathrm{L}^{-1}, 2,4-\mathrm{D}$ ("2, 4-dichlorophenoxyacetic acid") formed the optimal frequency (75.35\%) of white friable compact (WFC) callus. However, the root explant was less responsive for WFC callus induction. Organogenic WFC callus cultivated on MS medium fortified by kinetin $\left(1.0 \mathrm{mg} \mathrm{L}^{-1}\right)$ as well as BAP $\left(1.0 \mathrm{mg} \mathrm{L}^{-1}\right)$ revealed the highest shoot regeneration efficiency $(75.49 \%)$ with 48 shoots per callus. Adventitious shoots obtained from node and WFC callus of both leaf and root explants cultivated on MS medium increased by NAA $\left(2.0 \mathrm{mg} \mathrm{L}^{-1}\right.$ showed the optimal rooting of $76.97 \%$. Concomitantly, an elevated frequency of somatic embryogenesis (52.50\%) was recorded from leaf explants on MS medium using BAP $\left(0.5 \mathrm{mg} \mathrm{L}^{-1}\right)$ \& 2, 4-D (1.0 $\mathrm{mg} \mathrm{L}^{-1}$ ). Leaf explants were superior to node and root explants for somatic embryo initiation. The cotyledonary embryos were efficiently germinated into complete plantlets on a hormone-free MS medium. The plantlets gathered from organogenesis \& somatic embryo genesis was effectively acclimatized into phenomenally similar plants. This technique may be applicable for wide-range propagation, genetic engineering, and the formation of bioactive compounds.

\section{Introduction}

Vetiver (Vetiveria zizanioides) is synonymously called as (Chrysopogon zizanioides) comes to the Poaceae family and is broadly cultured in tropical as well as sub-tropical areas for the production of essential oil. In spite of its economic importance, it has certain environmental significance such as soil moisture conservation, reduction in soil erosion, and deduction of heavy metals (Sudhishri et al. 2008; Minh and Khoa 2009; Leauagvutiviroj et al. 2010). Naturally, sterile plant and has no rhizome or stolons as seed material for cultivation, but conventionally propagated through root segments or slips.

The secondary metabolites present in vetiver root extract have been extensively used as a major ingredient in perfumery and cosmetic industries (Bhuiyan et al. 2008; Bhushan et al. 2013). Further, a variety of potential bioactivities have been notified previously from its extract including antimicrobial, herbicidal, and pesticide properties (Mao 2004; Koul 2008; Adam 2008; Sangeetha and Stella 2012). The pharmacological properties present in extract possess curative properties such as anti-inflammatory, antiseptic, sedative, vulnery, cicatrisant, aphrodisiac, digestive, haematinic, carminative, stomachic, antiasthmatic, antispasmodic, antihelmetic, antigout, and diuretic (Bhushan et al. 2013). Further, the viscous oil extorted from the roots of the vetiver has authenticated the presence of aroma and several potential therapeutic properties (Massardo and Pripdeevech et al. 2006; Rotkittikhum et al. 2010). The phytochemical components obtained from oil extracts include, khositone, vetivone, ß-Humulene, vetiverol, khusimol, vetivene, terpenes, benzoic acid, khusimone, Tripene-4-ol, ß-Humulene, epizizianal, vetivenylvetivenate, isokhusimol, ß-vetivone, vetivazulene (Pareek and Kumar 2011). Furthermore, the massive biomass derived from the entire plant could be an amenable and alternate resource for biofuel manufacture (Sun et al. 2014). Although C. zizanioides has a sufficient quantity of varied secondary 
metabolites which could be utilized a novel phytomedicine, its population in natural habitat has become indiscriminately depleting due to pollen sterility, uncontrolled grazing, reaping by therapeutic professionals for making of folk medicine, deforestation, urbanization, and also due to unfavorable environmental factors.

Conventionally, vetiver has been propagated through root cuttings which have certain constraints such as inherent low viability, unsynchronized growth form, and also sluggish growth rate. These factors will impede the export of vetiver biomass across several nations. Thus, the actual requirement of biomass for oil extraction and biofuel production could not cope up with mounting commercial demands.

Henceforth, it is essential to propagate and conserve endangered or extinct germplasm by adopting the latest biotechnological technique i.e., regeneration via plant tissue culture (Deo et al. 2010; Anis and Ahmad 2016). Environmentally independent and year-round generation of genetically similar and valuable populations through micropropagation technique is highly indispensable to meet out the ever-increasing demands on commercial and industrial-scale (Hussain et al. 2018).

Despite the fact that there are a few explants with its pre-existing meristem of vetiver has been used to accomplish micropropagationstudies, such as shoot segment (Code et al. 2012), adventitious bud and axillary bud (Zhenrang et al. 2006; Kanokporn and Chonnikarn 2016), and inflorescence (Sangduen and Prasertsongskun 2009) and reported with low regeneration frequencies. However, callogenesis and somatic embryogenesis have not been reported in this species. Herein, we developed efficient reliable and reproducible regeneration protocols through organogenesis and somatic embryogenesis from node, root, and leaf sheath explants of $C$. zizanioides.

\section{Materials And Methods}

\section{Plant Materials}

The propagating material clumps of $C$. zizanioides have been brought from a village, Nochikkadu, Cuddalore District, Tamil Nadu. The clumps were grown in the potting blend (compost, soil, and sand) in the proportion of 1:1:1 and maintained under shade in the pot culture yard of "Department of Genetics and Plant Breeding, Annamalai University, Annamalai Nagar", India. Explants were collected from ex-vitro grown plants for optimization of regeneration methodology in C. zizanioides.

\section{Explants preparation}

Node, leaf sheath, and root explants were gathered from 30-day old plants and twenty minutes of washing is done with tap water and disinfected using $1 \%$ bavistin with continuous agitation. The materials are again rinsed with flowing tap water to eliminate residual bavistin. Again, explants were dipped in 0.1 percent "mercuric chloride" $\left(\mathrm{HgCl}_{2}\right)$ for 2 to 3 minutes, followed by 4 to 5 times cleaning with sterile filtered water to eliminate the traces of sterilizing agents. Explants such as nodal segments $(5 \mathrm{~mm})$, leaf $(5 \mathrm{~mm})$, and root segment $(5 \mathrm{~mm})$ were cut away from the source plants with the support of sterilized sharp scalpels \& forceps. Auxiliary buds and leaves and were cut off from the nodes and internodes by using a sharp scalpel blade. Identically, the cut may be given at the proximal end of the leaf sheath of explants.

\section{Culture media and conditions}


MS basal medium (Skoog and Murashige 1962) was added with different doses of PGRs ("Plant growth regulators") including kinetin, NAA: "a-naphthaleneacetic acid”, TDZ: "Thidiazuron”, 2, 4-D and BAP. The carbon source incorporated in the medium is sucrose $\left(30 \mathrm{~g} \mathrm{~L}^{-1}\right)$ and phytagel was employed in all media as a gelling agent at a $4.0 \mathrm{~g} \mathrm{~L}^{-1}$ rate. These thermostable PGRs were applied before autoclaving of media. The $\mathrm{pH}$ of the medium was varied to 5.8 with $1 \mathrm{~N} \mathrm{HCl}$ or1 $\mathrm{N} \mathrm{NaOH}$. The autoclaving of the culture media was done in an autoclave using steam sterilization on a $1.5 \mathrm{~kg} / \mathrm{cm}^{2}$ pressure and 121 degrees Celsius for fifteen minutes. Twenty milliliters of medium were poured into sterile culture tubes $(25 \times 150 \mathrm{~mm})$ and sealed with cotton plugs. Cool white fluorescent tubes were used in the chamber of plant growth to maintain a photoperiod of 16/8 hour with "light intensity" of $50 \mu \mathrm{mol} \mathrm{m} \mathrm{m}^{-2} \mathrm{~s}^{-1}$ ("Panasonic, Japan"). The PGR, as well as chemicals, were imported from Hi-media, and glasswares were brought from "Borosil”, India.

\section{Adventitious shoot culture}

Nodal portions were inoculated in MS media enriched with many levels of kinetin $\left(0.5,1.0,2.0 \& 4.0 \mathrm{mg} \mathrm{L}^{-1}\right)$, or $\operatorname{BAP}\left(0.5,1.0,2.0\right.$ and $\left.2.5 \mathrm{mg} \mathrm{L}^{-1}\right)$ or TDZ $\left(0.1,0.5,1.0 \& 2.0 \mathrm{mg} \mathrm{L}^{-1}\right)$ to achieve direct adventitious initiation. The control treatment was maintained by using MS medium without PGRs. Subculturing was performed with the same medium composition for every fortnight and kept until 8 weeks. Percentage of shoot organogenesis from explants and an average number of shoots/explants along with mean shoot duration were noted after six weeks of cultivation. On average, 20 explants were subjected to individual therapy and the tests were followed three times. The regeneration response was estimated with the help of the following formula. Regeneration response $(\%)=($ explants showing shoot regeneration number $\div$ explants cultured total number $) \times 100$.

\section{Shoot regeneration and callus induction}

Root and leaf segments of suitable size were incubated in MS medium with the several intensities of 2, 4-D (0.1, $0.2,0.5,1.0,1.5,2.0,3.0 \& 4.0 \mathrm{mg} \mathrm{L}^{-1}$ ) for initiation of callus. These cultures were incubated in dark at $28 \pm 1^{\circ} \mathrm{C}$ for 6 weeks and subcultured at 2 weeks intervals. Callus initiation Frequency of individual treatment was noted after 8 weeks of culture. The callus developmental nature was categorized as WFC ("white friable compact"), WNF ("white non-friable"), and no callus initiation (N). Twenty explants were subjected to individual replication,

three replications per experiment, and treatment was performed three times. Organogenic calli resulting from the above trials were subjected to media with various intensities of NAA from 0.5 to $1.0 \mathrm{mg} \mathrm{L}^{-1}$ blended with numerous intensities of $\operatorname{BAP}\left(0.5,1.0,2.0,3.0,5.0 \& 6.0 \mathrm{mg} \mathrm{L}^{-1}\right)$ respectively for initiation of adventitious shoots. Subculturing of these cultures was performed once in 2 weeks and continued for 6 weeks with the same medium concentration for adventitious shoot initiation. The fraction response of shoot organogenesis was observed from callus and a mean "number of shoots/callus pieces" after six weeks. The plantlet's nature was categorized as qualitatively +: "abnormal stunted shoots", ++: "normal leaves shoots", -: no shoots.

\section{Hardening and Rooting}

Transferring of shoots developed from "the nodes, internode explants, and shoots obtained from leaf sheath and root-derived calli to rooting media consisting of either hormone-free half-strength MS or half-strength MS + NAA $\left(0.5 \mathrm{mg} \mathrm{L}^{-1}\right)$ or full-strength MS basal medium or half MS + NAA $\left(1.0 \mathrm{mg} \mathrm{L}^{-1}\right)$ or full MS + NAA $\left(2.0 \mathrm{mg} \mathrm{L}^{-1}\right)$ or full MS + NAA $\left(2.5 \mathrm{mg} \mathrm{L}^{-1}\right)$ for 2-4 weeks. After root initiation from this culture, subculturing of inoculants into 
the fresh medium after 2 weeks was done and kept until four weeks. After four weeks fully developed rooted shoots have been uprooted from the media and cleaned thoroughly thrice with" sterile water to eliminate the adhered material and transferred to plastic pots with the potting mixture for hardening. Then the plastic containers were coated with plastic bags and holes were created for gaseous exchange. These potted plants were kept for 2 weeks in the chamber of plant growth and then shifted on to the greenhouse condition. The polyethylene covers were gradually detached from well-established plantlets. The plant survival ratio in the greenhouse and at the field was assessed. After four weeks, the proportion of rooting response, the mean number of roots/shoots and root duration have been noted for each treatment. For each replication, ten adventitious shoots were utilized with 3 replications per experiment, and treatment was performed three times.

\section{Plant regeneration and somatic embryogenesis}

For somatic embryogenesis nodal, leaf, as well as root parts were surface cultivated on MS medium extended with BAP $\left(0.5 \& 1.0 \mathrm{mg} \mathrm{L}^{-1}\right)$ along with numerous intensities of 2, 4-D (0.5, 1.0, 3.0 \& $\left.5.0 \mathrm{mg} \mathrm{L}^{-1}\right)$ respectively. The lower cut end of the leaf sheath explants was placed in a resting position and embedded in the culture medium. Subculturing of inoculants was done once in two weeks and kept until 4 to 6 weeks at $23 \pm 2{ }^{\circ} \mathrm{C}, \mathrm{RH}$ of $60-65 \%$ and "light intensity" of $30 \mu \mathrm{mol} \mathrm{m} \mathrm{m}^{-2} \mathrm{~s}^{-1}$ within cool white pipes of the fluorescent with a photoperiod of $16 / 8$ hours in a growing chamber (Panasonic, Japan). The rate of explants developing "somatic embryos" was noted after four to 6 weeks and an average number of somatic embryos/explants was found after six weeks of inoculation. The different phases of somatic embryos such as cotyledonary, torpedo, heart, and globular, derived from MS medium consisting of 2, 4-D (1.0 mg L-1) as well as BAP of $\left(0.5 \mathrm{mg} \mathrm{L}^{-1}\right)$ were subjected to either MS + NAA of $\left(0.5,1.02 .0 \& 2.5 \mathrm{mg} \mathrm{L}^{-1}\right)$ or half or full strength for the transformation of "somatic embryos" into entire plantlets. Subculturing of cultures was done at the interval of two weeks and kept up to six weeks. The regeneration frequencies of somatic embryos were noted after four to six weeks. Twenty explants were used with three replications per experiment and treatment was replicated three times. The fully developed plantlets with a well-organized rooting system were detached from the culture tube, and cleaned with sterile water to detach adhering agar, and were moved to sterilized potting blend and maintained in a greenhouse for acclimatization. The plantlet's survival ability was examined in both greenhouse and in field conditions.

\section{Statistical analysis}

The CRD ("Completely randomized design") was employed as an experimental design for all experiments conducted in this research. The data collected from these experiments were analyzed through ANOVA ("analysis of variance") with the aid of SPSS Version 10 (SPSS, Chicago, IL) software. The significance differences within the treatment means were compared with the aid of DMRT ("Duncan's Multiple Range test") at a 5 percent probability level. The resulted data were represented as mean \pm SE ("Standard Error").

\section{Results}

\section{Induction of multiple shoots}

Nodal segments from one-month-old seedlings (Fig. 1a) were subjected to MS medium augmented with numerous kinetin, TDZ, and BAP levels for proliferation and induction of adventitious shoots. Shoots appeared from explants after two weeks of culture (Fig. 1b-f). However, completely emerged shoots and shoot elongation 
was found after four weeks of culture. Here the direct organogenesis pathway from the nodal segments without production of callus stage and visible shoot buds was identified within 4 weeks. The nodal explants cultivated on MS media augmented using BAP $\left(1.0 \mathrm{mg} \mathrm{L}^{-1}\right)$ recorded high frequency $(72.20 \%)$ of shoot initiation with the maximum shoots number (10.04) and with the greater shoot duration of $8.1 \mathrm{~cm}$ (Table 1; Fig. 1h).

Table 1. Effect of different concentrations of BAP, TDZ and kinetin on regeneration of adventitious shoots from nodal segments of $C$. zizanioides

\begin{tabular}{|c|c|c|c|c|c|c|}
\hline \multicolumn{3}{|c|}{$\begin{array}{l}\text { Phytohormones } \\
(\mathrm{mg} / \mathrm{L})\end{array}$} & \multirow[t]{2}{*}{$\begin{array}{l}\text { Regeneration } \\
\text { response (\%) }\end{array}$} & \multirow[t]{2}{*}{$\begin{array}{l}\text { Mean no. of shoots/ } \\
\text { explants }\end{array}$} & \multirow{2}{*}{$\begin{array}{l}\text { Mean } \\
\text { shoot } \\
\text { length } \\
(\mathrm{cm})\end{array}$} & \multirow[t]{2}{*}{$\begin{array}{l}\text { Nature of } \\
\text { plantlets }\end{array}$} \\
\hline BAP & TDZ & Kinetin & & & & \\
\hline 0.0 & 0.0 & 0.0 & $0.0 \pm 0.0 \mathrm{i}$ & $0.0 \pm 0.0 f$ & $0.0 \pm 0.0 \mathrm{~g}$ & - \\
\hline 0.5 & - & - & $31.45 \pm 1.3 d$ & $1.0 \pm 0.5 \mathrm{e}$ & $2.5 \pm 0.1 d$ & + \\
\hline 1.0 & - & - & $72.20 \pm 3.1 a$ & $10 \pm 0.4 a$ & $8.1 \pm 0.4 a$ & ++ \\
\hline 2.0 & - & - & $53.00 \pm 1.6 b$ & $6.0 \pm 0.3 b$ & $2.0 \pm 0.1 d$ & ++ \\
\hline 2.5 & - & - & $25.43 \pm 1.0 \mathrm{e}$ & $1.0 \pm 0.1 \mathrm{e}$ & $2.3 \pm 0.1 d$ & + \\
\hline- & 0.1 & & $21.89 \pm 1.0 f$ & $1.0 \pm 0.2 \mathrm{e}$ & $1.8 \pm 0.1 e$ & + \\
\hline - & 0.5 & & $43.63 \pm 2.0 c$ & $3.0 \pm 0.2 c$ & $4.0 \pm 0.1 b$ & ++ \\
\hline- & 1.0 & & $19.87 \pm 0.9 f$ & $0.5 \pm 0.2 e$ & $0.8 \pm 0.0 f$ & + \\
\hline - & 2.0 & & $06.89 \pm 0.3 \mathrm{~h}$ & $1.2 \pm 0.4 \mathrm{e}$ & $1.2 \pm 0.1 \mathrm{e}$ & + \\
\hline- & - & 0.5 & $11.45 \pm 0.5 \mathrm{~g}$ & $1.0 \pm 0.1 \mathrm{e}$ & $0.9 \pm 0.0 f$ & + \\
\hline- & - & 1.0 & $04.66 \pm 0.2 \mathrm{~h}$ & $2.2 \pm 0.1 d$ & $2.9 \pm 0.1 d$ & + \\
\hline - & - & 2.0 & $35.28 \pm 1.5 d$ & $3.0 \pm 0.2 c$ & $3.4 \pm 0.2 c$ & ++ \\
\hline- & - & 2.5 & $07.88 \pm 0.3 \mathrm{~h}$ & $1.0 \pm 0.5 \mathrm{e}$ & $1.7 \pm 0.1 \mathrm{e}$ & + \\
\hline
\end{tabular}

Means having the same letter in columns are not significantly different by Duncan's multiple range test $(P<$ 0.05).

Each data represent mean \pm SE of three independent experiments

TDZ and Kinetin indicated less response than BAP for shoot induction as well as proliferation. No shoot induction without cytokinin (control) was found on MS medium. The shoot induction frequency was compared with other PGRs as well. Since the findings, it was found that nodal segments exhibited $43.63 \%$ of regeneration efficiency TDZ $\left(0.5 \mathrm{mg} \mathrm{L}^{-1}\right)$ and $35.28 \%$ with TDZ at $2.0 \mathrm{mg} \mathrm{L}^{-1}$.

\section{Callus Induction And Shoot Organogenesis}


Leaf and root explants were nurtured onto MS medium amended with several levels of 2, 4-D (0.1, 0.2, 0.5, 1.0, 1.5, 2.0, $3.0 \mathrm{mg} \mathrm{L}^{-1}$ ) for callus induction. It was detected after 2 weeks (Fig. 1i) and a well-developed callus was noted after 4 weeks (Fig. 1j). Callus induction frequency of both explants was raised with the rise in levels of 2 , 4-D from 0.2 to $0.5 \mathrm{mg} \mathrm{L}^{-1}$ for root and from $\left(0.5\right.$ to $\left.1.0 \mathrm{mg} \mathrm{L}^{-1}\right)$ for leaf explants. Further rise in concentration decreased the potential of callus formation (Table 2). After eight weeks of cultivation, the highest rate of callus formation (75.35\%) was identified to be 2, 4-D (1.0 $\mathrm{mg} \mathrm{L}^{-1}$ ) in (Fig. 1k) from leaf explants on MS and 64.28\% from root explants cultivated on MS augmented by 2, 4-D (0.5 $\left.\mathrm{mg} \mathrm{L}^{-1}\right)$ in (Fig. 10). Thus, leaf explant shows a better callus induction response than that root explants. There was no callusing response in case of nodal explants in the similar media containing 2, 4-D.

Table 2

Effect of 2, 4-D concentrations on callus induction from leaf and root explants of C. zizanioides

\begin{tabular}{|c|c|c|c|c|}
\hline $\begin{array}{l}\text { 2,4-D } \\
(\mathrm{mg} / \mathrm{L})\end{array}$ & $\begin{array}{l}\% \text { of leaf } \\
\text { forming callus }\end{array}$ & Nature of callus & $\begin{array}{l}\% \text { of root } \\
\text { forming callus }\end{array}$ & Nature of callus \\
\hline 0.0 & $0.0 \pm 0.0 \mathrm{~h}$ & $\mathrm{~N}$ & $0.0 \pm 0.0 \mathrm{~h}$ & $\mathrm{~N}$ \\
\hline 0.1 & $18.96 \pm 0.9 \mathrm{~g}$ & WNF & $45.36 \pm 2.1 \mathrm{c}$ & WFF \\
\hline 0.2 & $33.29 \pm 1.4 \mathrm{e}$ & WNF & $50.70 \pm 2.4 b$ & WFC \\
\hline 0.5 & $36.73 \pm 1.8 d$ & WNF & $64.28 \pm 3.4 a$ & WFC \\
\hline 1.0 & $75.35 \pm 3.7 a$ & WFC & $42.60 \pm 2.1 \mathrm{c}$ & WNF \\
\hline 1.5 & $50.98 \pm 1.5 b$ & WFC & $32.00 \pm 1.6 d$ & WNF \\
\hline 2.0 & $46.23 \pm 2.2 c$ & WNF & $26.20 \pm 1.3 e$ & WNF \\
\hline 3.0 & $29.60 \pm 1.3 f$ & WNF & $18.90 \pm 0.8 f$ & WNF \\
\hline 4.0 & $20.02 \pm 1.0 \mathrm{~g}$ & WNF & $11.45 \pm 0.5 \mathrm{~g}$ & WNF \\
\hline \multicolumn{5}{|c|}{$\begin{array}{l}\text { Means having the same letter in columns are not significantly different by Duncan's multiple range test ( } P \text { < } \\
0.05) \text {. }\end{array}$} \\
\hline \multicolumn{5}{|c|}{ N-no response, (N), WFC- white friable compact, WNF-white non friable } \\
\hline \multicolumn{5}{|c|}{ Each data represent mean \pm SE of three independent experiments } \\
\hline
\end{tabular}

Calli obtained from root explant at 2, 4-D from $0.2 \mathrm{mg} \mathrm{L}^{-1}$ to $0.5 \mathrm{mg} \mathrm{L}^{-1}$ along with leaf explant at 2, 4-D from $1.0 \mathrm{mg} \mathrm{L}^{-1}$ to $1.5 \mathrm{mg} \mathrm{L}^{-1}$ were" observed to be compact, friable as well as white in nature, whereas the rest were noted to be non-friable, white and spongy in nature (Table 2). These embryogenic WFC callus cultures procured from root explants and leaf explants were moved onto MS medium comprising numerous levels and blends of NAA along with BAP (Table 3). Both leaf sheath and root-derived calli showed the highest shoot regeneration rate on MS medium augmented using NAA of $\left(1.0 \mathrm{mg} \mathrm{L}^{-1}\right)$ and BAP of $\left(1.0 \mathrm{mg} \mathrm{L}^{-1}\right)$. Callus obtained from leaf demonstrated an optimum shoot regeneration frequency (75.49\%) with 40 shoots per callus after six weeks of culture (Fig. 11-n). Similarly, root-derived calli also recorded the maximum frequency of shoot generation (60.20\%) with 25 shoots per callus (Fig. $1 p$ - r). This observation indicated that indirect organogenesis pathway is achievable from leaf and root explants of $C$. zizanioides 
Table 3

Effect of different concentrations of BAP, TDZ and kinetin on regeneration of adventitious shoots from callus cultures of C. zizanioides

\begin{tabular}{|llllllll|}
\hline $\begin{array}{l}\text { Phytohormones } \\
(\mathrm{mg} / \mathrm{L})\end{array}$ & Leaf & & & Root & \\
\hline BAP & NAA & $\begin{array}{c}\text { Shoot } \\
\text { regeneration } \\
(\%)\end{array}$ & $\begin{array}{l}\text { Mean no. of } \\
\text { shoots/callus }\end{array}$ & $\begin{array}{l}\text { Nature } \\
\text { of } \\
\text { plantlets }\end{array}$ & $\begin{array}{l}\text { Shoot } \\
\text { regeneration } \\
(\%)\end{array}$ & $\begin{array}{l}\text { Mean no. of } \\
\text { shoots/callus }\end{array}$ & $\begin{array}{l}\text { Nature } \\
\text { of } \\
\text { plantlets }\end{array}$ \\
\hline 0.0 & 0.0 & $0.0 \pm 0.0 \mathrm{i}$ & $0.0 \pm 0.0 \mathrm{~g}$ & - & $0.0 \pm 0.0 \mathrm{k}$ & $0.0 \pm 0.0 \mathrm{j}$ & - \\
\hline 0.5 & 0.5 & $33.80 \pm 1.0 \mathrm{f}$ & $4.0 \pm 0.1 \mathrm{~d}$ & + & $33.53 \pm 1.5 \mathrm{f}$ & $3.1 \pm 0.2 \mathrm{f}$ & + \\
\hline 0.5 & 1.0 & $36.00 \pm 2.2 \mathrm{e}$ & $2.0 \pm 0.8 \mathrm{e}$ & + & $38.70 \pm 1.9 \mathrm{~d}$ & $5.1 \pm 0.2 \mathrm{~d}$ & + \\
\hline 1.0 & 0.5 & $52.23 \pm 2.3 \mathrm{~b}$ & $20.5 \pm 1.5 \mathrm{~b}$ & ++ & $45.65 \pm 2.2 \mathrm{~b}$ & $12.6 \pm 0.9 \mathrm{~b}$ & ++ \\
\hline 1.0 & 1.0 & $75.49 \pm 4.0 \mathrm{a}$ & $48.0 \pm 0.4 \mathrm{a}$ & ++ & $60.20 \pm 2.5 \mathrm{a}$ & $25.6 \pm 1.2 \mathrm{a}$ & ++ \\
\hline 2.0 & 0.5 & $48.30 \pm 0.5 \mathrm{c}$ & $15.3 \pm 1.5 \mathrm{c}$ & + & $42.63 \pm 2.0 \mathrm{c}$ & $9.5 \pm 0.6 \mathrm{c}$ & + \\
\hline 2.0 & 1.0 & $42.03 \pm 2.4 \mathrm{~d}$ & $4.0 \pm 0.5 \mathrm{~d}$ & + & $38.31 \pm 1.8 \mathrm{~d}$ & $4.1 \pm 0.2 \mathrm{e}$ & + \\
\hline 3.0 & 0.5 & $37.57 \pm 1.8 \mathrm{e}$ & $2.7 \pm 0.5 \mathrm{e}$ & + & $35.78 \pm 1.6 \mathrm{e}$ & $3.1 \pm 0.2 \mathrm{~g}$ & + \\
\hline 3.0 & 1.0 & $34.82 \pm 1.6 \mathrm{f}$ & $2.2 \pm 0.4 \mathrm{e}$ & + & $29.23 \pm 1.3 \mathrm{~g}$ & $2.5 \pm 0.1 \mathrm{~h}$ & + \\
\hline 5.0 & 0.5 & $25.78 \pm 1.2 \mathrm{~g}$ & $2.0 \pm 0.8 \mathrm{e}$ & + & $25.56 \pm 1.2 \mathrm{~h}$ & $2.0 \pm 0.1 \mathrm{~h}$ \\
\hline 5.0 & 1.0 & $22.54 \pm 1.1 \mathrm{~g}$ & $2.0 \pm 0.5 \mathrm{e}$ & + & $20.44 \pm 1.0 \mathrm{i}$ & $1.0 \pm 0.0 \mathrm{i}$ & + \\
\hline 6.0 & 0.5 & $22.34 \pm 1.4 \mathrm{~g}$ & $1.1 \pm 0.6 \mathrm{f}$ & + & $19.28 \pm 0.8 \mathrm{i}$ & $1.0 \pm 0.0 \mathrm{i}$ \\
\hline 6.0 & 1.0 & $15.65 \pm 1.0 \mathrm{~h}$ & $1.5 \pm 0.5 \mathrm{f}$ & + & $11.21 \pm 0.4 \mathrm{j}$ & $1.0 \pm 0.0 \mathrm{i}$ & + \\
+
\end{tabular}

\section{Rooting Of Adventitious Shoots}

Shoots obtained from indirect as well as direct organogenesis were removed from cultivation and subjected to the rooting medium comprising of full-strength MS using NAA $\left(2.0,2.5 \mathrm{mg} \mathrm{L}^{-1}\right)$,half and full MS medium with NAA (0.5 \& $\left.1.0 \mathrm{mg} \mathrm{L}^{-1}\right)$, hormone-free half-strength, for effective root regeneration (Table 4). Root initiation was detected at the base of in vitro shoots after 2 weeks of inoculation (Fig. 1s) and a well-developed root system was visible after 4 weeks (Fig. 1t and $u$ ). Results indicated that maximum response of root initiation (76.97\%) was found with full-strength MS amended by NAA $\left(2.0 \mathrm{mg} \mathrm{L}^{-1}\right)$ with an average of 16 roots per plant with the root duration of $4.01 \pm 0.2 \mathrm{~cm}$. However, there is less response of root initiation in the half-strength hormone-free medium. 
Table 4

Effect of different levels of NAA and MS medium strengths on rooting of adventitious shoots regenerated through direct and indirect organogenesis of $C$. zizanioides

\begin{tabular}{|llll|}
\hline Culture medium & Rooting (\%) & $\begin{array}{l}\text { Mean no. of } \\
\text { roots /shoot }\end{array}$ & $\begin{array}{l}\text { Average } \\
\text { root length }(\mathbf{c m})\end{array}$ \\
\hline Half MS & $12.25 \pm 0.6 \mathrm{f}$ & $2.00 \pm 0.1 \mathrm{f}$ & $0.98 \pm 0.0 \mathrm{~d}$ \\
\hline Full MS & $26.62 \pm 1.3 \mathrm{e}$ & $3.00 \pm 0.2 \mathrm{e}$ & $1.20 \pm 0.0 \mathrm{~d}$ \\
\hline Half MS + NAA $(0.5 \mathrm{mg} / \mathrm{L})$ & $35.34 \pm 1.7 \mathrm{~d}$ & $5.50 \pm 0.3 \mathrm{~d}$ & $1.56 \pm 0.1 \mathrm{~d}$ \\
\hline Half MS + NAA $(1.0 \mathrm{mg} / \mathrm{L})$ & $40.01 \pm 2.0 \mathrm{c}$ & $8.76 \pm 0.4 \mathrm{c}$ & $2.08 \pm 0.1 \mathrm{~d}$ \\
\hline Full MS + NAA $(2.0 \mathrm{mg} / \mathrm{L})$ & $76.97 \pm 3.8 \mathrm{a}$ & $16.00 \pm 0.8 \mathrm{a}$ & $4.01 \pm 0.2 \mathrm{a}$ \\
\hline Full MS + NAA $(2.5 \mathrm{mg} / \mathrm{L})$ & $54.21 \pm 2.6 \mathrm{~b}$ & $10.50 \pm 0.5 \mathrm{~b}$ & $3.14 \pm 0.2 \mathrm{~b}$ \\
\hline $\begin{array}{l}\text { Values followed by the same letter are not significantly different at } P<0.05 \text { according to Duncan's multiple } \\
\text { range tests. }\end{array}$ & & \\
\hline Each data represent mean \pm SE of three independent experiments & \\
\hline
\end{tabular}

\section{Regeneration Via Somatic Embryogenesis}

Node, leaf, and root explants were surface sterilized and inoculated in the MS medium augmented with many mixtures and levels of 2, 4-D as well as BAP for initiation of somatic embryos (Table 5). The proximal part of the nodal segments was placed vertically in the culture tube, whereas leaf and root surface were allowed to firmly contact in the medium. 
Table 5

Somatic embryogenesis from node, leaf, and root explants of $C$. zizanioides

\begin{tabular}{|c|c|c|c|c|c|c|c|}
\hline \multicolumn{2}{|c|}{ PGRs (mg/L) } & \multicolumn{2}{|l|}{ Node } & \multicolumn{2}{|l|}{ Leaf } & \multicolumn{2}{|l|}{ Root } \\
\hline $\begin{array}{l}2,4- \\
D\end{array}$ & BAP & $\mathrm{R}(\%)$ & MNS & $\mathrm{R}(\%)$ & MNS & $\mathrm{R}(\%)$ & MNS \\
\hline 0.0 & 0.0 & $00.00 \pm 0.0 i$ & $0.0 \pm 0.0$ & $00.00 \pm 0.0 h$ & $0.0 \pm 0.0 \mathrm{~g}$ & $00.00 \pm 0.0 i$ & $0.0 \pm 0.0 i$ \\
\hline 0.5 & 0.5 & $4.23 \pm 0.6 \mathrm{gh}$ & $5.26 \pm 0.3 i$ & $13.26 \pm 1.5 e$ & $4.1 \pm 0.2 \mathrm{~g}$ & $5.64 \pm 0.6 h$ & $6.1 \pm 0.4 h$ \\
\hline 0.5 & 1.0 & $5.36 \pm 0.5 f$ & $\begin{array}{l}8.03 \pm \\
0.2 \mathrm{gh}\end{array}$ & $15.34 \pm 0.3 d$ & $10.1 \pm 0.4 e$ & $7.61 \pm 0.8 g$ & $12.1 \pm 0.5 \mathrm{ef}$ \\
\hline 1.0 & 0.5 & $32.88 \pm 1.9 a$ & $23.6 \pm 0.5 a$ & $52.50 \pm 2.5 a$ & $\begin{array}{l}46.2 \pm \\
1.5 a\end{array}$ & $40.80 \pm 2.5 a$ & $38.2 \pm 1.7 a$ \\
\hline 1.0 & 1.0 & $17.55 \pm 1.5 b$ & $18.1 \pm 0.4 b$ & $27.44 \pm 1.8 b$ & $\begin{array}{l}28.5 \pm \\
0.6 b\end{array}$ & $33.50 \pm 1.2 b$ & $25.5 \pm 2.0 b$ \\
\hline 3.0 & 0.5 & $14.0 \pm 0.8 c$ & $16.6 \pm 0.6 c$ & $18.25 \pm 1.2 c$ & $15.1 \pm 1.8 c$ & $25.13 \pm 1.4 c$ & $22.1 \pm 1.5 b c$ \\
\hline 3.0 & 1.0 & $13.6 \pm 0.8 \mathrm{~cd}$ & $14.4 \pm 0.2 d$ & $15.61 \pm 0.9 d$ & $\begin{array}{l}13.1 \pm \\
1.2 \mathrm{~d}\end{array}$ & $20.22 \pm 2.1 d$ & $15.1 \pm 1.4 d$ \\
\hline 5.0 & 0.5 & $12.26 \pm 0.6 \mathrm{de}$ & $13.5 \pm 0.5 \mathrm{de}$ & $11.45 \pm 0.6 \mathrm{ef}$ & $10.6 \pm 1.4 \mathrm{e}$ & $17.50 \pm 1.2 \mathrm{e}$ & $13.6 \pm 1.2 \mathrm{e}$ \\
\hline 5.0 & 1.0 & $9.43 \pm 0.4 f$ & $9.52 \pm 0.6 f$ & $10.62 \pm 0.5 g$ & $9.1 \pm 0.8 \mathrm{ef}$ & $15.60 \pm 1.2 \mathrm{ef}$ & $10.1 \pm 0.6 \mathrm{~g}$ \\
\hline
\end{tabular}

Initiation of somatic embryos from explants was observed from all the treatments of 2, 4-D \& BAP blends, indicating the optimization of PGRs for somatic embryogenesis. However, the greatest rate of somatic embryogenesis was notified from leaf (52.50\%), followed by root (40.80\%) and node segments (32.88\%) on MS medium expanded by 2, 4-D (1.0 $\left.\mathrm{mg} \mathrm{L}^{-1}\right)$ as well as BAP $\left(0.5 \mathrm{mg} \mathrm{L}^{-1}\right)$ (Table 5$)$. Somatic embryos of all stages were noted after 6 weeks of incubation. Concomitantly, leaf explant formed a substantially highest number of somatic embryos (46.2), followed by root (38.2) and node explants (23.6). Heart shape and torpedo embryos from node (Fig. 2a), cotyledonary stages from leaf (Fig. 2b), and roots (Fig. 2c) were observed during the 4th week of the culture period. Entire somatic embryos of all phases were acquired and transported to a hormonefree MS medium for germination into complete plantlets. Germination and proliferation of cotyledonary stage embryos (Fig, $2 \mathrm{~d}$ and e) into complete plants with an efficient rooting system were observed after 6 weeks (Fig. 2f). Thereafter, in vitro established somatic plantlets were moved to sterile pot blend \& adjusted in the greenhouse (Fig. 2h).

\section{Hardening Of In Vitro Raised Plantlets}

The better survivability of regenerated plantlets was achieved through hardening. In this study, the plantlets regenerated via organogenesis as well as somatic embryogenesis was moved to plastic containers covered with sand, sterilized soil along with FYM mix in a 1:1:1 ratio for acclimatization. These hardened plantlets were coated with a plastic sheet and drenched with a half-strength MS medium twice a week. Acclimatized plants 
were cultured in the chamber of a plant growth for 15 days and subsequently transferred to a greenhouse and then on the field condition. The survival rates of regenerated plants were evaluated in the greenhouse as well as in field conditions. Findings indicated that organogenic plantlets survived 70 percent in the greenhouse and $60 \%$ at field conditions, whereas, somatic embryogenesis derived plantlets survived $78 \%$ at greenhouse conditions and $65 \%$ at field conditions (Table 6). The complete protocol involving regeneration by organogenesis as well as somatic embryogenesis of $C$. zizanioides was presented in Fig. 3.

Table 6

Acclimatization and survival rate capability of in vitro regenerated plantlets of $C$. zizanioides

\begin{tabular}{|lll|}
\hline Mode of regeneration & \multicolumn{2}{l|}{ Survival rate (\%) } \\
\cline { 2 - 3 } & Greenhouse & Field condition \\
\hline Organogenesis & 70 & 60 \\
\hline Somatic embryogenesis & 78 & 65 \\
\hline CD @ 5\%(0.05) & 2.49 & 4.20 \\
\hline *Mean of three replications & \\
\hline
\end{tabular}

\section{Discussion}

About four million people in rural regions have entirely depended upon medicinal plants as a primary source of health care (Petrovska 2012). Plant tissue culture can be an alternate methodology for germplasm conservation and mass production of quality bio-active compounds (Ahmed et al. 2019; Grigoriadou et al. 2019). Hence, the current study was set to regulate reliable regeneration protocols via organogenesis \& "somatic embryogenesis" in C. zizanioides.

\section{Regeneration through direct organogenesis}

Some of the reports on in vitro regeneration of vetiver using explants like leaf crown (Leupin et al. 2000), leaves (Mucciarelli et al. 1993), young inflorescence (Sangduen et al. 2009), meristem tip culture (Chitra et al. 2014) and mesocotyl culture (George et al. 1999). In this direct shoot organogenesis involving nodal segments has been successfully established from in vivo grown seedlings of $C$. zizanioides. Several reports have authenticated the superior role of nodal explant over the other types to accomplish micropropagation in medicinal plants such as Mentha piperita (Sujana 2011), Withania somnifera (Fatima 2012), Agastache foeniculum (Moharami 2014), Teucrium scorodonia (Makowczyńska 2016), and Spermacoce hispida (Deepak et al. 2019). Earlier literature has proved the existence of positive correlations among explant types, the shoot proliferation rate, and influences of cytokinin (Sajid et al. 2011; Dantu and Bhojwani 2013; Lebedev et al. 2018).

Here, cytokinins such as kinetin, TDZ, and BAP were used to assess the shoot induction efficacy from nodal explants of $C$. zizanioides. Among the three cytokinins tested, BAP exhibited maximum performance for adventitious shoot regeneration than TDZ and kinetin.

Yang et al. (2013) also stated about the effect of BAP in MS medium on direct regeneration in vetiver. The effect of BAP in shoot organogenesis was previously noted in several medical plants like Canscora 
decussate (Loganathan 2016), Scutellaria alpine (Grzegorczyk 2016), Dracocephalum forrestii (Weremczuk 2018), and Gymnema sylvestre (Isahet al. 2019). Interestingly, we noticed maximum shoot proliferation (72.2\%) from node explant cultured onto MS fortified with BAP @ $1 \mathrm{mg} \mathrm{L}^{-1}$. Similar trends of findings were also observed in Securidaca longipedunculata (Lijalem et al., 2020) and Trichosanthes dioica (Tiwari et al. 2010). The nodal segment is considered to be the best explant type when compared to other types for initiation of direct shoot regeneration and proliferation and also requires only a lesser concentration of cytokinin, according to the Algabri et al. survey (2019).

\section{Callus induction}

Callus culture offers a wide variety of applications in pharmacological research, rather than direct organogenesis (Efferth 2018). The efficacy of callus initiation is reliant on the medium composition and types of the explants (Romano and Gonçalves 2013; Nordine et al. 2014). Leaf and root parts from in vitro seedlings of $C$. zizanioides were used as explants for callogenesis. In this study, even inflorescence of vetiver also used for callus development (Somporn 2003)using synthetic 2, 4-D, and auxin. 2, 4-D performs a significant part in plant tissue culture methods for callogenesis, which has been already stated in V. zizanioides (Mucciarelli et al. 1993; yang et al. 2008) proliferation as well as somatic embryogenesis (Gao et al. 2011). Further, it has been said that 2, 4-D has a noteworthy effect on the biochemical and molecular processes of callus with stimulating certain gene expression, controlling the metabolism of endogenous IAA as well as regulating DNA methylation (Pan 2010). The maximum frequency of friable compact callus was found in MS medium fortified using 2, 4-D at 0.5

$\mathrm{mg} \mathrm{L}^{-1} \& 1.0 \mathrm{mg} \mathrm{L}^{-1}$ from root and leaf explants, respectively. Similar studies on callogenesis using leaf and root explants were reported in several medicinally important herbs such as Trachyspermum ammi (Fazeli-nasab 2018), Vitex negundo (Chowdhury 2011), Piper betel (Junairiah 2019), Ledebouria revoluta (Haque 2018), Celastrus paniculatus (Moola et al. 2020) and Rhinacanthus nasutus (Reshi et al. 2018), and Rosa hybrida (Liu et al. 2018). Further, callus is the most amenable and optimal tissue for the formation of novel secondary metabolites (Benjamin et al. 2019). It has been noticed that the leaf explants showed a better callusing response than root explants.

\section{Regeneration from callus}

The compact friable calli obtained from culturing of leaf and root explants were transferred onto shoot initiation medium augmented with varied levels and mixtures of BAP and NAA. It has been found that both the explants exhibited the highest frequency of shoot redevelopment on MS by NAA of $1.0 \mathrm{mg} \mathrm{L}^{-1}$ and BAP of $1.0 \mathrm{mg} \mathrm{L}^{-1}$ as stated in V. zizanioides (Sompornpailin et al. 2016; Sompornpailin 2009). Also the Zinc Oxide Nanoparticles showed some impact on calli derived regenerants in $V$. zizanioides (Khunchuay et al. 2017). Similar effects of auxin and cytokinin combinations for shoot initiation were well studied from several medicinal plant types like Rauvolfia serpentine (Singh et al. 2009), Celosia argentea (Bakar et al. 2014), Lallemantia iberica (Ozdemir et al. 2014), and Indigo feraviscosa (Rajabudeen 2016). Further, leaf-derived calli documented a better response that was produced from root explants on shoot regeneration over the calli.

\section{Rooting of adventitious shoots}

The rooting efficiency and survival rate of hardened plants at in vivo conditions are the factors for successful in vitro propagation (Reshi 2018). In vitro rooting hastened the adaptability of plants to ex vitro conditions (Krupa- 
Malkiewicz and Mglosiek 2016). Regardless of medium, auxin enhances the root initiation to in vitro regenerated adventitious shoots (Martins et al. 2013; Shekhawat and Manokari 2018). In the current work, fullstrength MS medium amended with $2.0 \mathrm{mg} \mathrm{L}^{-1} \mathrm{NAA}$ illustrated a better-rooting response than other levels. Concomitantly, the results of Widoretno et al. (2017) also corroborated the present results that NAA @ 1.0 mg L

1 noted better-rooting efficiency on C. zizanioides. 154 Concomitantly, the results of Widoretno et al. (2017) also corroborated the present results that NAA @ $1.0 \mathrm{mg} \mathrm{L-1}$ noted better-rooting efficiency on C. zizanioides. The NAA efficiency in the roots of in vitro regenerated shoots was well recognized in Rotula aquatica (Chithra 2004), Phyllanthus caroliniensis (Catapan et al. 2012), Andrographis paniculata (Hossain et al. 2016), Tinospora cordifolia (Mridulaet al. 2017).

\section{Regeneration via somatic embryogenesis}

Somatic embryos are the unicellular origin and can be maintained as an embryogenic culture for a long period (Tomiczak 2019). Here the somatic cells are differentiated into the whole plant by the embryogenesis process. In vitro embryogenesis is the direct approach where the somatic embryos are directly developed from explant tissues (Mazri and Meziani 2015). Many diverse and complex factors affect somatic embryogenesis (Deo et al. 2010). The concentration, type, and combination of regulators for plant growth are the main variables that influenced somatic embryogenesis as well as plant regeneration (De Almeida et al. 2012).

Here, node leaf, and root segments as explants for somatic embryogenesis have been accomplished. High-rate somatic embryogenesis was detected at BAP $\left(1.0 \mathrm{mg} \mathrm{L}^{-1}\right)$ and 2, 4-D $\left(0.5 \mathrm{mg} \mathrm{L}^{-1}\right)$ combinations from all explants. The mixtures of auxins with cytokinins were accounted for to induce considerable somatic embryogenesis in Fraxinus excelsior (Capuana et al. 2007),Eremochloa ophiuroides (Liu et al. 2008), Swertia chirayita (Chandra and Kumar 2014), and Lachenalia viridiflora (Kumar et al. 2016). The current research demonstrates that MS medium augmented with 2, 4-D and BAP is essential for friable embryogenic callus development in $C$. zizaniodes. The results of this research correspond to previous studies on somatic embryogenesis of Chrysanthemum indicum (Datta and Mandal 2005), "Brachiaria brizantha" (Cabral et al. 2011), Rosa hybrida (Bao et al. 2012), "Prosopis laevigata" (González-Buendíaet al. 2012), Vitis vinifera (Dai et al. 2015) and Curcuma amada (Raju et al. 2015).

The transformation of somatic embryos into mature plantlets is crucial for a successful in vitro plant regeneration system. The torpedo and cotyledonary embryos were harvested from 2, 4-D, and BAP treatments and were subjected to germinations. Results showed significant conversion and germinations of somatic embryos were noticed on half-strength MS medium. Published literature has confirmed the effectiveness of halfstrength MS for "somatic embryo germination" in other types as well (Paul 2011; Raju 2013; Kumar, 2015; Khan et al. 2015). The simultaneous transformation of the shoot and root axis from the matured somatic embryos into plantlets is crucial in the somatic embryogenesis mode of regeneration (Pandey et al. 2013).

\section{Hardening of somatic plants}

Success in micropropagation is based on the successful ex vitro establishment of a fully regenerated in vitro plant. Fully grown healthy plants from experimental tubes were carefully removed and transferred to the potting mixture for acclimatization. The plantlet's survival rate was judged in the greenhouse and subsequently in field conditions. Results revealed that the plantlets derived from somatic embryogenesis survived at higher rate when 
compared to organogenic plantlets (Table. 6). Regardless of the acclimatizing environment, similar observations on survival rate and adaptability were recorded from organogenesis and somatic embryogenesis derived plants (Bhagya et al. 2013; Deepak et al. 2019).

\section{Conclusion}

The demonstrated protocol of plant regeneration via organogenesis and somatic embryogenesis using node, root, and leaf explants of $C$. zizaniodes. Callogenesis from leaf and roots explants may facilitate the extraction of novel bioactive compounds. The present protocol might open the ways to scale up research on genetic engineering to synthesize novel drugs, germplasm conservation, and micropropagation at industrial level.

\section{Abbreviations}

2, 4-D 2, 4-dichlorophenoxyacetic acid

BAP 6-benzylaminopurine

IBA Indole-3-butyric acid

IAA Indole-3-acetic acid

NAA a-Naphthaleneacetic acid

\section{Declarations}

\section{Conflict of interest}

The manuscript was approved by all authors after reading it and declared that there is no conflict of interest.

\section{References}

1. Adam RP, Nguyen S, Johnston DA, Park S, Provin TL, Habte M (2008) Comparison of vetiver root essential oils from cleansed (bacteria-and fungus-free) VS. non-cleansed (normal) vetiver plants. Biochem Syst Ecol 36:177-182

2. Ahmed A, Gehad M, Vitantonio P, Paola L, Moemen S, Hanafy (2019) In vitro regeneration through organogenesis in egyptian chickpea. Plant Biosyst 153(6):835-842

3. Ahmed A, Narayan P (2019) In vitro micropropagation studies in Spilanthes acmella murr. Int J Sci Res 8:2

4. Anis M, Ahmad N (2016) Plant tissue culture: propagation conservation and crop improvement. Springer, Singapore

5. Bahman F (2018) The effect of explants, BAP and 2, 4-D on callus induction of Trachyspermum ammi. Potravinarstvo Slovak J Food Sci 12(1):578-586

6. Bakar DA, Bakrudeen AA, Rosna MT (2014) In vitro callus induction and plant regeneration of Celosia argentea- an important medicinal plant. Braz Arch Biol Techno 57(6):860-866 
7. Bao Y, Liu G, Shi X, Xing W, Ning G, Liu J, Bao M (2012) Primary and repetitive secondary somatic embryogenesis in Rosa hybrida 'Samantha'. Plant Cell Tiss Org Cult 109:411-418

8. Benjamin ED, Ishaku GA, Peingurta FA, Afolabi AS (2019) Callus culture for the production of therapeutic compounds. Am j Plant Biol 4:76-84

9. Bhagya N, Chandrashekar KR, Karun A, Bhavyashree U (2013) Plantlet regeneration through indirect shoot organogenesis and somatic embryogenesis in Justicia gendarussa Burm. f., a medicinal plant. J Plant Biochem Biotechnol 22(4):474-482

10. Bhojwani SS, Dantu PK (2013) Micropropagation. In: Bhojwani SS, Dantu PK (eds) Plant Tissue Culture: an Introductory Text. Springer, New Delhi, pp 245-274

11. Bhuiyan MDNI, Chowdhury JU, Begum J (2008) Essential oil in roots of Vetiveria zizanioides (L.) Nash ex small from Bangladesh. Bangl J Bot 37(2):213-215

12. Bhushan B, Kumar SS, Tanuja S, Lalit S, Hema A (2013) Vetiveri zizanioides (Linn.) Nash : A pharmacological overview. Int Res J Pharm 4(7):18-20

13. Buendía-González L, Estrada-Zúñiga ME, Orozco-Villafuerte J, Cruz-Sosa F, Vernon- Carter EJ (2012) Somatic embryogenesis of the heavy metal accumulator Prosopis laevigata. Plant Cell Tiss Org Cult 108:287-296

14. Cabral GB, Carneiro VTC, Lacerda AL, do Valle CB, Martinelli AP, Dusi DMA (2011) Somatic embryogenesis and organogenesis in apomictic and sexual Brachiaria brizantha. Plant Cell Tiss Org Cult. 107: 271-282

15. Capuana M, Petrini G, Marco AD, Giannini R (2007) Plant regeneration of common ash Fraxinus excelsior (L.) by somatic embryogenesis. In Vitro Cell Dev Biol Plant 43:101-110

16. Catapan E, Otuki M, Viana A (2012) In vitro culture of Phyllanthus caroliniensis (Euphorbiaceae). Plant Cell Tiss Org Cult 62:195-202

17. Cedo M, Licas M, Zara R, Guzman C (2012) Enhanced plantlet regeneration and in vitro root production in vetiver (Vetiveria zizanioides (L.) Nash). Philipp Agric Sci 95:344-351

18. Chithra M, Martin KP, Sunandakumari C, Madhusoodanan PV (2004) Silver nitrate induced rooting and flowering in vitro on rare rhoeophytic woody medicinal plant Rotula aquatica Lour. Indian J Biotechnol 3(3):418-421

19. Chitra T, Jayashree S, Rathinamala J, Suganya A (2014) Preliminary studies in vitro regeneration of Vetiveria zizanioides through meristem tip culture. J Bio Innov 3(4):189-196

20. Chowdhury FB, Azam FMS, Hassan MM, Jahan R, Anita Chowdhury R, Seraj S, Khatun Z, Rahmatullah M (2011) Studies with callus induction of Vitex negundo: An aromatic medicinal plant. Am Eurasian J Sustain Agric 5:6-14

21. Dai L, Zhou Q, Li R, Du Y, He J, Wang D, Cheng S, Zhang J, Wang Y (2015) Establishment of a picloraminduced somatic embryogenesis system in Vitis vinifera cv. chardonnay and genetic transformation of a stilbene synthase gene from wild growing Vitis species. Plant Cell Tiss Org Cult 121:397-412

22. De Almeida M, de Almeida CV, Mendes GE (2012) Pre-procambial cells are niches for pluripotent and totipotent stem-like cells for organogenesis and somatic embryogenesis in the peach palm: a histological study. Plant Cell Rep 31:1495-1515

23. Deepak KV, Narayanan GS, Prakash M, Murugan S, Anandan R (2019) Efficient plant regeneration and histological evaluations of regenerants through organogenesis and somatic embryogenesis in Spermacoce 
hispida L. An underutilized medicinally important plant. Ind Crops Prod 134:292-302

24. Deo P, Tyagi A, Taylor M, Harding R, Becker D (2010) Factors affecting somatic embryogenesis and transformation in modern plant breeding. South Pac J Nat Appl Sci 28:27-40

25. Efferth T (2018) Biotechnology applications of plant callus cultures. Engineering 5:50-59

26. Fatima N, Anis M (2012) Role of growth regulators on in vitro regeneration and histological analysis in Indian ginseng (Withania somnifera L.). Dunal Physiol Mol Biol Plants 18(1):59-67

27. Gao J, Li J, Luo C, Yin L, Li S, Yang G, He G (2011) Callus induction and plant regeneration in Alternanthera philoxeroides. Mol Biol Rep 2:1413-1417

28. George MM, Subramanian RB (1999) High frequency regeneration of Vetiveria zizanioides (L.) via mesocotyl culture. Phytomorphology 49:309-313

29. Gonçalves S, Romano A (2013) In vitro culture of lavenders (Lavandula spp.) and the production of secondary metabolites. Biotechnol Adv 31:166-174

30. Grigoriadou K, Krigas N, Sarropoulou V (2019) In vitro propagation of medicinal and aromatic plants: the case of selected Greek species with conservation priority. In Vitro Cell Dev Biol Plant 55:635-646

31. Grzegorczyk-Karolak I, Kuźma Ł, Wysokińska H (2016) In vitro cultures of Scutellaria alpina as a source of pharmacologically active metabolites. Acta Physiol Plant 38:7

32. Haque Sk, Moquammel AC, Biswajit G (2018) Callus mediated shoot organogenesis and cytologically stable plants of Ledebouria revoluta: An ethnomedicinal plant with promising antimicrobial potency. J Genet Eng Biotechnol 6(2):645-651

33. Hossain M, Urbi Z (2016) Effect of naphthalene acetic acid on the adventitious rooting in shoot cuttings of Andrographis paniculata (Burm.f.) Wall. ex Nees: An important therapeutical herb. Int J Agron. 6

34. Hussain SA, Ahmad N, Anis M (2018) Synergetic effect of TDZ and BA on minimizing the post-exposure effects on axillary shoot proliferation and assessment of genetic fidelity in Rauvolfia tetraphylla (L.). Rend. Lincei Sci Fis Nat 29:109-115

35. Junairiah M, Manuhara A, NimatuzahrohYN, Lilis S (2019) Callus induction and bioactive compounds from Piper betle L. var nigra. IOP Conference Series: Earth and Environmental Science. 217(1): 012026

36. Kanokporn S, Chonnikarn K (2016) Synergistic effects of bap and kinetin media additives on regeneration of vetiver grass. Aust J Crop Sci 10(5):726-731

37. Khan MA, Abbasi BH, Ali M, Adil M, Hussain I (2015) Temporal variations in metabolite profiles at different growth phases during somatic embryogenesis of Silybum marianum L. Plant Cell Tiss Org Cult 120:127139

38. Kumar V, Chandra S (2014) High frequency somatic embryogenesis and synthetic seed production of the endangered species. Swertia chirayita Biologia 69:186-192

39. Kumar V, Moyo M, Van Staden J (2016) Enhancing plant regeneration of Lachenalia viridiflora, a critically endangered ornamental geophyte with high floricultural potential. Sci Hortic 211:263-268

40. Leaungvutiviroj C, Piriyaprin S, Limtong P, Sasaki K (2010) Relationships between soil microorganisms and nutrient contents of Vetiveria zizanioides (L.) Nash and Vetiveria nemoralis (A.) Camus in some problem soils from Thailand. App Soil Ecolo 46:95-102 
41. Lebedev V, Arkaev M, Dremova M, Pozdniakov I, Shestibratov K (2018) Effects of growth regulators and gelling agents on ex vitro rooting of raspberry. Plants $8(1): 3$

42. Leupin RE, Leupin M, Ehret C, Erismann KH, Witholt (2000) Compact callus induction and plant regeneration of a non-flowering vetiver from java. Plant Cell Tiss Org Cult 62:115-123

43. Lijalem T, Feyissa T (2020) In vitro propagation of Securidaca longipedunculata (Fresen) from shoot tip: an endangered medicinal plant. J Genet Eng Biotechno 18(1):1-10

44. Liu J, Feng H, Ma Y (2018) Effects of different plant hormones on callus induction and plant regeneration of miniature roses (Rosa hybrida L.). Hortic Int J 2(4):201-206

45. Liu MX, Yang J, Lu SY, Guo ZF, Lin XP, Wu H (2008) Somatic embryogenesis and plant regeneration in centipede grass Eremochloa ophiuroides [Munro] Hack. In Vitro Cell Dev Biol Plant. 44: 100-104

46. Loganathan K, Narmatha BV (2016) Effect of Growth Regulators on Rapid Micropropagation and Antioxidant Acitivity of Canscora decussata (Roxb.) Roem. and Schult. - A Threatened Medicinal Plant. Asian Pac J Reprod 5(2):161-170

47. Mandal AKA, Datta SK (2005) Direct somatic embryogenesis and plant regeneration from ray florets of Chrysanthemum. Biol Plant 49:29-33

48. Mao L, Henderson G, Laine RA (2004) Germination of various weed species in response to vetiver oil and nootkatone. Weed Technol 18(2):263-267

49. Khunchuay C, Phuwiwat W, Sompornpailin K (2009) Callus induction and plant regeneration from Vetiveria zizanioides (L.) Nash. Paper presented at the 21st Annual meeting and international conference of the thai society for biotechnology: Queen Sirikit National Convention Center, Bangkok, Thailand, 24-25

50. Khunchuay C, Sompornpailin K (2017) Beneficial effects of zinc oxide nanoparticles on plant regeneration of vetiver grass (Vetiveria zizanioides I. nash). Applied Mechanics Materials 866:25-28

51. Krupa-Malkiewicz M, Mglosiek O (2016) The influence of IBA, IAA and NAA on rooting of celosia argentea var.cristata (L.) Kuntze in vitro culture. Folia Pomer Univ Technol Stetin Agric Aliment Pisc Zootech 325:3946

52. Martins JP, Schimildt ER, Alexandre RS, Santos BR, Magevski GC (2013) Effect of synthetic auxins on in vitro and ex vitro bromeliad rooting. Pesqui Agropecu Trop 43(2):138-146

53. Massardo D, Senatore F, Alifano P, Giudice LD, Pontieri P (2006) Vetiver oil production correlates with early root growth. Biochem Syst Eco 34:376-382

54. Mazri MA, Meziani R (2015) Micropropagation of Date Palm: A Review Cell Biol. 4: 160

55. Moharami L, Hosseini B, Ravandi EG, Jafari M (2014) Effects of plant growth regulators and explant types on in vitro direct plant regeneration of Agastache foeniculum, an important medicinal plant. In Vitro Cell Dev Biol-Plant 50:707-711

56. Moola AK, Kumari BDR (2020) Rapid propagation of Celastrus paniculatus Willd.: an endangered medicinal plant through indirect organogenesis. Vegetos 33:277-285

57. Mridula K, Parthibhan S, Senthil KT, Rao MV (2017) In vitro organogenesis from Tinospora cordifolia (wild.) Miers - A highly valuable medicinal plant. S Afr J Bot. 113: 84-90

58. Mucciarelli M, Gallino M, Scannerini S, Maffei M (1993) Callus induction and plant regeneration in Vetiveria zizanioides. Plant Cell Tiss Org Cult 35(3):267-271 
59. Murashige T, Skoog F (1962) A revised medium for rapid growth and bioassays with tobacco tissue cultures. Physiol Plant 15:4730-4497

60. Nordine A, Tlemcani CR, El-Meskaoui A (2014) Regeneration of plants through somatic embryogenesis in Thymus hyemalis Lange, a potential medicinal and aromatic plant. In Vitro Cell Dev Biol Plant 50:19-25

61. Ozdemir F, Yildirim MU, Kahriz M (2014) Efficient micropropagation of highly economic, medicinal and ornamental plant Lallemantia iberica (bieb.) Fisch. and C. A. Mey Biomed Res Int. 476346

62. Pan Z, Zhu S, Guan R, Deng X (2010) Identification of 2, 4-D-responsive proteins in embryogenic callus of Valencia sweet orange (Citrus sinensis Osbeck) following osmotic stress. Plant Cell Tiss Org Cult 103(2):145-153

63. Pareek A, Kumar A (2011) Ethnobotanical and pharmaceutical uses of Vetiveria zizanioides (Linn) nash: a medicinal plant of Rajasthan. Int J Life Sci Pharma Res 3:12-18

64. Paul S, Dam A, Bhattacharyyarya A, Bandyopadhyay TK (2011) An efficient regeneration system via direct and indirect somatic embryogenesis for the medicinal tree Murraya koenigii. Plant Cell Tiss Org Cult 105:271-283

65. Petrovska BB (2012) Historical review of medicinal plants' usage. Pharmacogn Rev 6(11):1-5

66. Pripdeevech P, Wongpornchai S, Promsiri A (2006) Highly volatile constituents of Vetiveria zizanioides roots grown under different cultivation conditions. Molecules 11:817-826

67. Rajabudeen E, Ganthi AS, Sivasubramanian S, Subramanian MP (2016) In vitro regeneration of Indigofera viscosa Lam. J Biosci 22:53-58

68. Raju CS, Aslam A, Shajahan A (2015) High-efficiency direct somatic embryogenesis and plant regeneration from leaf base explants of turmeric (Curcuma longa L.). Plant Cell Tiss Org Cult 122:79-87

69. Reshi NA, Sudarshana MS, Girish HV (2018) In vitro micropropagation of Rhinacanthus nasutus (L) Kurz. Int J Biodivers Conserv 10:357-364

70. Rotkittikhun P, Kruatrachue M, Pokethitiyook P, Baker AJM (2010) Tolerance and accumulation of lead in Vetiveria zizanioides and its effect on oil production. J Environ Biol 31:329-334

71. Sajid AAA, Naveed NH, Majid A, Saleem A, Khan UA, Jafery FI, Naz S (2011) Initiation, proliferation and development of micro- propagation system for mass scale production of banana through meristem culture. Afr J Biotechnol 10:15731-15738

72. Sangduen N, Prasertsongskun S (2009) Regeneration and application: from suspension cultured-derived inflorescences of Vetiveria zizanioides (L.) Nash. to selection of herbicide-resistant cell. AU J T 12(3):135148

73. Sangeetha D, Stella D (2012) Screening of microbial activity of vetiver extracts against certain pathogenic microorganisms. Int J Pham Biol Arch 3(1):197-203

74. Shekhawat MS, Manokari M (2018) In vitro Multiplication, micromorphological studies and ex vitro rooting of Hybanthus Enneaspermus (L. ) F. Muell. - a rare medicinal plant. Acta Bot Croat. 77 (1): 80-87

75. Singh P, Singh A, Shukla AK, Singh L, Pande V, Nailwal TK (2009) Somatic embryogenesis and in vitro regeneration of an endangered medicinal plant sarpgandha (Rauvolfia serpentina L.). Indian J Sci 6:74-79

76. Somporn P (2003) Plant regeneration from callus culture of vetiver (Vetiveria zizanioides nash). Songklanakarin J. Sci. Technol. 25(5) 
77. Sompornpailin K, Khunchuay C (2016) Synergistic effects of bap and kinetin media additives on regeneration of vetiver grass (Vetiveria zizanioides I. nash). Aust J Crop Sci 10(05):726-731

78. Sudhishri S, Dass A, Lenka NK (2008) Efficacy of vegetative barriers for rehabilitation of degraded hill slopes in eastern India. Soil Till Res 99:98-107

79. Sujana P, Naidu CV (2011) High frequency rapid plant regeneration from shoot tip and nodal explants of Mentha piperita (L.) - An important multipurpose medicinal plant. J Phytol 3(5):9-13

80. Sun P, Zhang W, Yin F, Zhao X, Lui J, Chen Y, Lui S (2014) Biogas production potential of transgenic Vetiveria zizanioides in mesophilic bath anaerobic digestion. Sci Res Essay 9(9):293-296

81. Tasiu I (2019) De novo in vitro shoot morphogenesis from shoot tip - induced callus cultures of Gymnema sylvestre (Retz.) R. Br. Ex. Sm. Boil Res 52:3

82. Tiwari AK, Singh D, Tripathi S, Mishra N, Singh RB (2010) Effect of BAP and Kinetin on shoot initiation of Trichosanthes dioica; an important medicinal plant. Med Plants - Int J Phytomed Relat Ind 2:59-61

83. Tomiczak K, Mikuła A, Niedziela A, Wójcik-Lewandowska A, Domżalska L, Rybczyński JJ (2019) Somatic embryogenesis in the family gentianaceae and its biotechnological application. Front Plant Sci 10:762

84. Weremczuk JI, Kuźma Ł, Kiss A, Grzegorczyk -KI (2018) Effect of cytokinins on shoots proliferation and rosmarinic and salvianolic acid B production in shoot culture of Dracocephalum forrestii W. W. Smith Acta Physiol Plant 40:1-10

85. Widoretno W, Fauziah A, Indriyani S, Utomo EP (2017) Clonal propagation of Vetiveria zizanioides L. through tissue culture technique. Indones J Essent Oil 2:38-44

86. Yang BB, Xia HP, Zhen-Rong MA (2007) Study on tissue culture of Vetiveria zizanioides. Acta Prataculturae Sinica 16:93-99

87. Yang B, Wu G, Ma Z, Xia H (2008) Efficient regeneration system and agrobacterium-mediated transformation of vetiveria zizanioides (I.) nash. Pak J Bot. 40(2)

88. Zhenrang M, Bingbing Y, Hanping X (2006) Effecting factors of somatic embryogenesis and plant regeneration in vetiver. J Trop Subtrop Bot 14:55-60

\section{Figures}



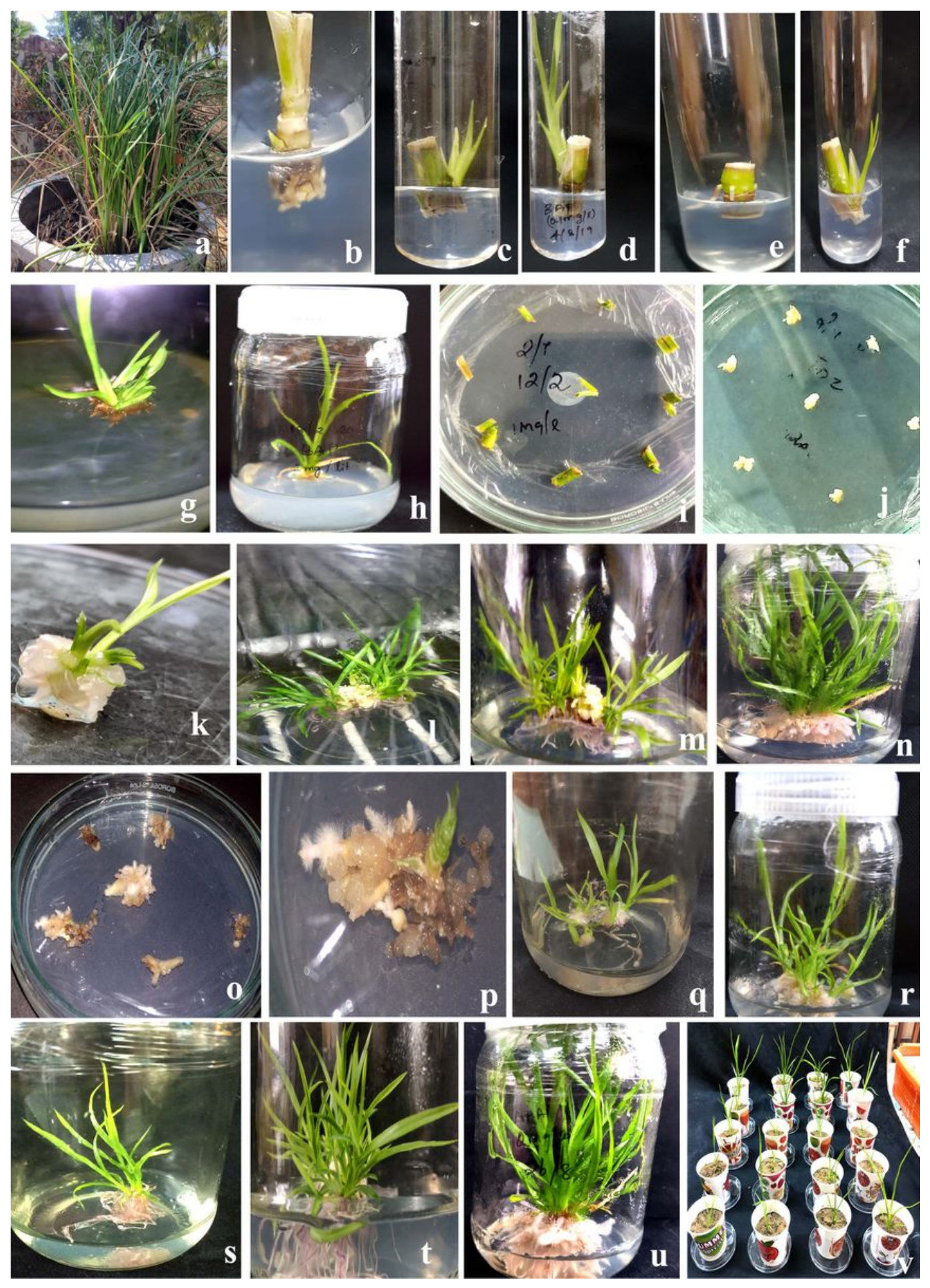

Figure 1

In vitro regeneration of $\mathrm{C}$. zizanioides through direct (a-h) and indirect organogenesis (i-v). (a) Stock plants established in pot culture; (b \& c) Shoot initiation from node on MS using 1.0 mg L- 1BAP after 1 week (b) 2 weeks (c); (d, e \& f) Response of nodal segments on different cytokinins i.e single shoot on MS with BAP (0.1 $\mathrm{mg} \mathrm{L}-1$ (d)), only rooting at $2.0 \mathrm{mg} \mathrm{L-1TDZ} \mathrm{(e)} \mathrm{and} \mathrm{stunted} \mathrm{shoot} \mathrm{on} 4.0 \mathrm{mg}$ L- 1 kinetin; (g \& h) Various shoots on MS using BAP(1.0 mg L- 1) after four weeks (g) and elongated shoots after six weeks (h); (i\& j) Callus initiation from leaf segments on MS using 2, 4-D (1.0 mg L- 1) after 2 weeks (i) four weeks (j); (k-n) Shoot initiation from leaf derived callus on MS with NAA $(1.0 \mathrm{mg} L-1)$ and BAP $(1.0 \mathrm{mg} L-1)$ after four weeks 
(k), Shoot elongation and proliferation after eight weeks ( $\mathrm{I}-\mathrm{n})$; (o) Callus induction form root segments on MS using2, 4-D (0.5 mg L- 1) after four weeks; ( $p$ - $r$ ) Shoot redevelopment from root-originated embryogenic callus on MS with BAP of (1.0 mg L- 1$)$ and NAA of $(1.0 \mathrm{mg} \mathrm{L}-1)$ after six weeks (p), Many shoots initiation and elongation after 8 weeks (q \& r); (s - u) Rooting of shoots on MS using NAA(2.0 mg L- 1) after two weeks (s) \& four weeks ( $t$ and $u) ;(v)$ Somatic plants acclimatized in pot mixture. Scale bars $(a=1 \mathrm{~cm}, b-f=1 \mathrm{~mm}, \mathrm{~g}-\mathrm{i}=0.5$ $\mathrm{cm}, \mathrm{k}-\mathrm{n}=1 \mathrm{~cm}, \mathrm{q} \& \mathrm{p}=1 \mathrm{~mm}, \mathrm{q}-\mathrm{u}=1 \mathrm{~cm}, \mathrm{v}=2 \mathrm{~cm}$ ).
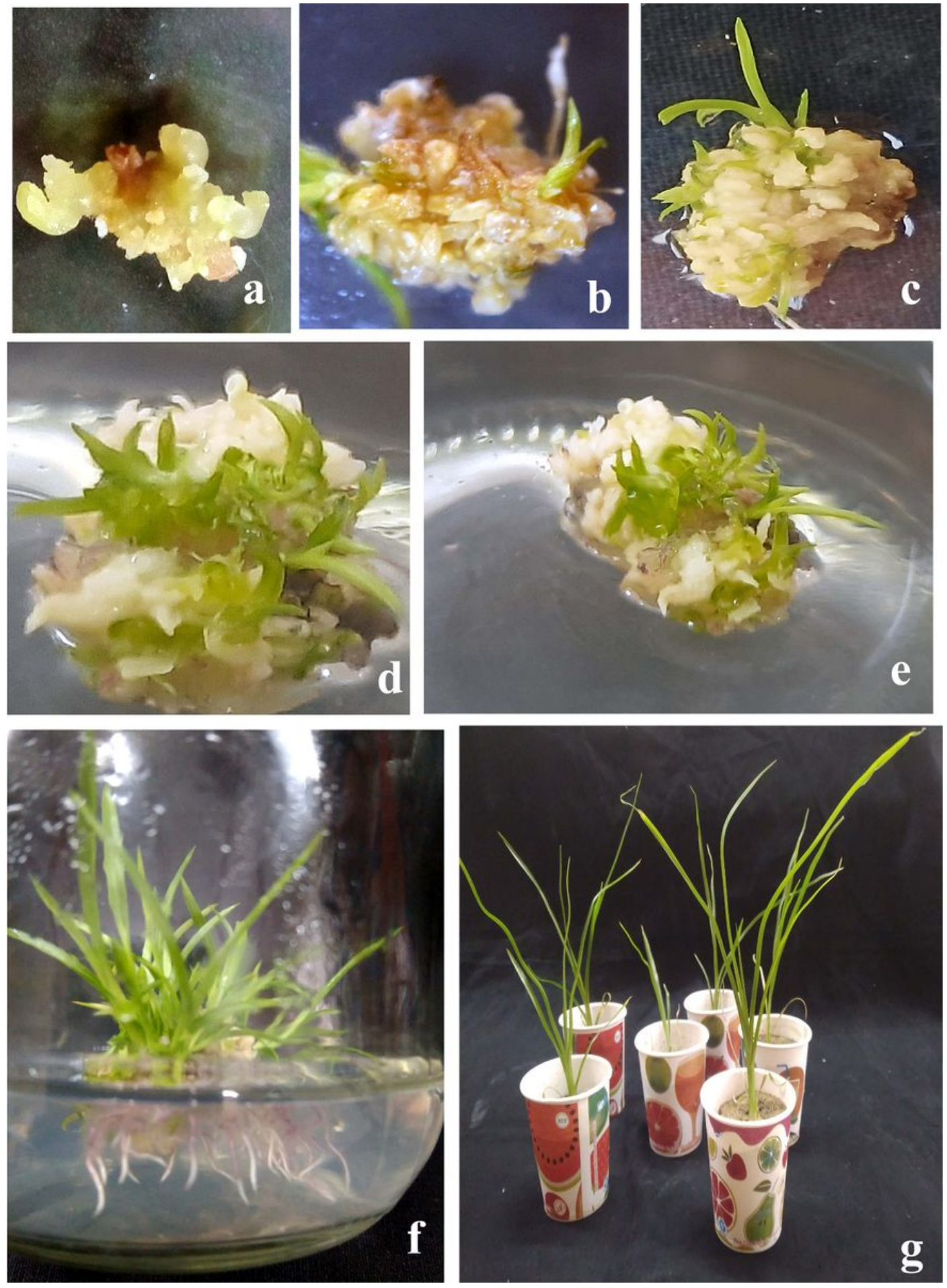

Figure 2 
Somatic embryogenesis in C. zizanioides from explants cultivated on MS fortified using 2, 4-D (1.0 mg L- 1) as well as BAP $(0.5 \mathrm{mg} L-1)$. (a-c) Clusters of somatic embryos from the node (a), asynchronous cotyledonary embryos from leaf (b) and root (c) after six weeks; ( $-f$ ) Germination of cotyledonary staged embryo on MS medium ( $\mathrm{d} \& \mathrm{e}$ ) after two weeks, complete plants with shoots and roots after four weeks (f); (g) Somatic plants acclimatized in pot mixture before transferring to the soil. Scale bars $(a, b, c, d$ and e $=1 \mathrm{~mm}, f=0.5 \mathrm{~cm}, \mathrm{~g}=1$ $\mathrm{cm})$.

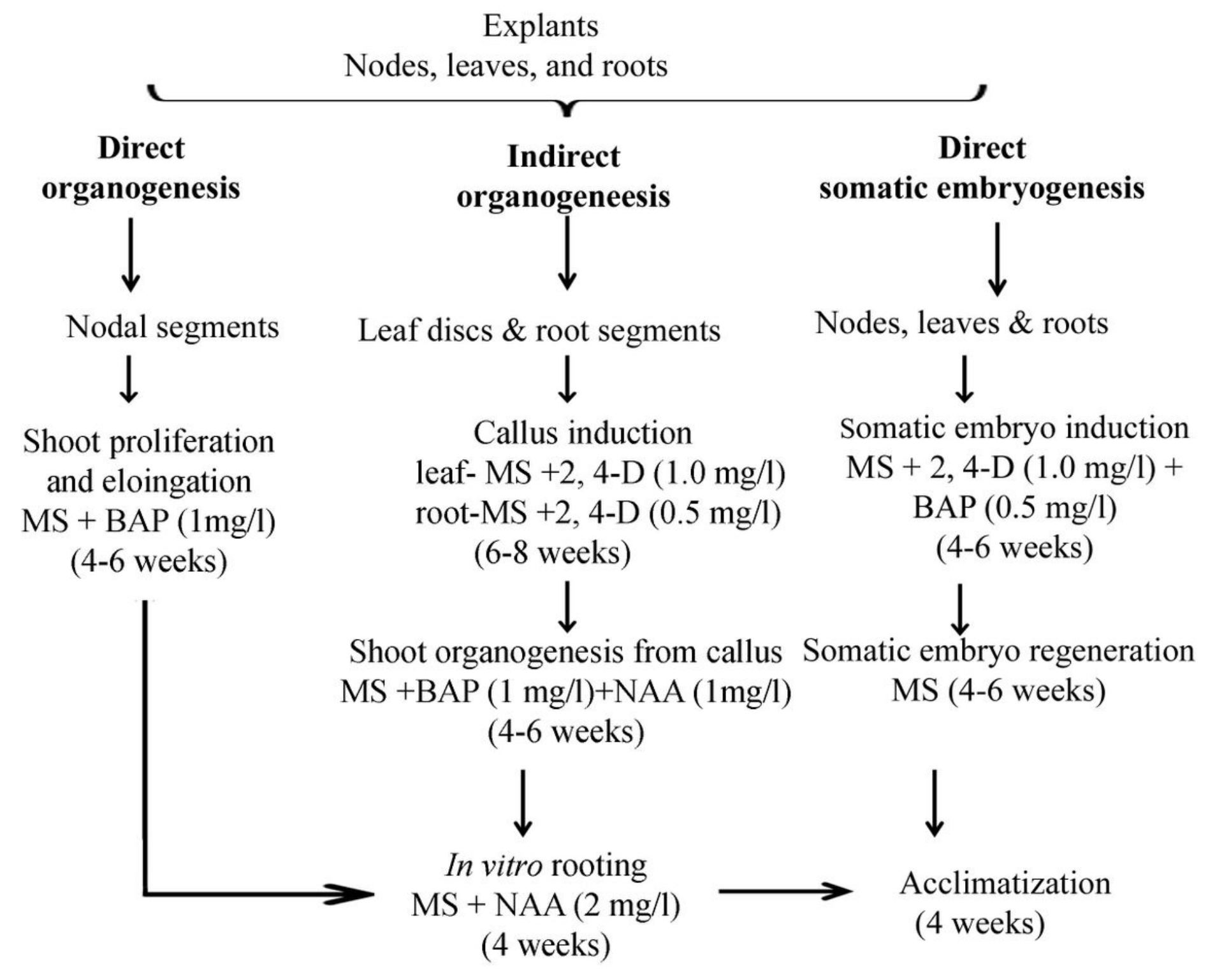

Figure 3

Outline of morphogenic pathways involved in micropropagation of C. zizanioides from different explants 